\title{
On the testing of large PV arrays
}

\author{
F. Martínez-Moreno* , E. Lorenzo, J. Muñoz and R. Moretón \\ Instituto de Energía Solar-Universidad Politécnica de Madrid (IES-UPM), E.T.S.I Telecomunicación, Ciudad Universitaria s/n, Madrid, \\ Spain
}

\begin{abstract}
This paper reports on the IES-UPM experience from 2006 to 2010 in the field of the characterization of PV arrays of commercial large PV plants installed in Spain within the framework of the profitable economic scenarios associated to feed-in tariff laws. This experience has extended to $200 \mathrm{MW}$ and has provided valuable lessons to minimize uncertainty, which plays a key role in quality assurance procedures. The paper deals not only with classic $I-V$ measurements but also with watt-metering-based procedures. Particular attention is paid to the selection of irradiance and cell temperature sensors. Copyright (C) 2011 John Wiley \& Sons, Ltd.
\end{abstract}

\section{KEYWORDS}

PV array characterization; PV power; field test; $L V$ curve; wattmeter

*Correspondence

F. Martínez-Moreno, Instituto de Energía Solar-Universidad Politécnica de Madrid (IES-UPM), E.T.S.I. Telecomunicación, Ciudad

Universitaria s/n, 28040 Madrid, Spain

E-mail: francisco.martinez@ies-def.upm.es

\section{INTRODUCTION}

Between 2006 and 2008, the size and number of PV plants installed in Spain has grown exponentially as a consequence of the feed-in tariff established under Spanish laws [1]. A total of $3412 \mathrm{MW}$ were installed just from January 2006 to December 2008 [2]. This process has encompassed the need for quality assurance procedures. The IES-UPM has been involved in the field-testing of about $40 \mathrm{PV}$ plants, which account for around $200 \mathrm{MW}$. A previous paper has dealt with inverters performance [3] Now, we report on the PV array characterization. Obviously, the real power of PV arrays plays the key role in the energy yield, which is the final goal of commercial projects.

Short testing time, low uncertainty and repeatability of results are key aspects of the general quality assurance procedures. The state-of-the-art of large PV array characterization refers to few international standards [47] and also to some particular experiences typically carried out with research or demonstration PV arrays [8,9]. However, as far as we know, experiences within the framework of fully commercial projects are almost non- existent. The large amount of consultancy requested to the IES-UPM during the Spanish PV boom also reflects the lack of widely accepted procedures at the state-of-the-art.

Nowadays, the quality control of PV installations more often relies on standard test conditions (STC) power control of samples of individual PV modules, carried out at specialized laboratories before their in-field installation [10-12]. That allows for assuring initial power delivered from the PV factory, but does not exclude the further occurrences of undesired phenomena such as initial light degradation, hot spots, 'polarization' and so on, which also forms part of field realities [13-19]. Moreover, that does not allow for the control of power losses due to soiling, mismatching and wiring. This framework favours the flourishing of significant disparities between effective and nominal PV array STC power, $P_{\text {NOMINAL, }}$ which is defined here as the sum of the STC power of the modules, as given by their manufacturers. As a representative example, Figure 1 shows the histogram of STC power from $I-V$ curves measured at the inverter entry by the IES-UPM at the aforementioned $200 \mathrm{MW}$. On average, effective values are $94.3 \%$ of nominal ones. Still worse, about $25 \%$ of these PV arrays exhibit effective power below $-10 \%$ of the 


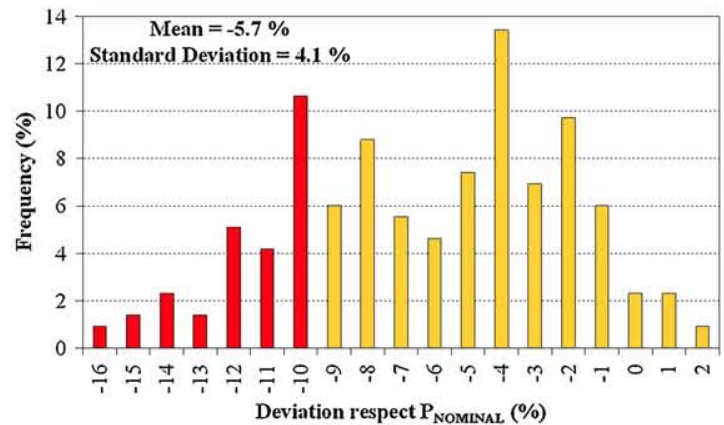

Figure 1. Histogram of STC power from $I-V$ curves of arrays measured at the inverter entry by the IES-UPM on a representative sample of about $200 \mathrm{MW}$ distributed in $40 \mathrm{PV}$ plants. About $25 \%$ of these PV arrays, the dark columns, have effective power below $-10 \%$ of nominal values.

nominal values. These results can be interpreted as an argument in favour of promoting the contractual consideration of testing entire PV arrays under real operation conditions.

\section{MEASURING OPERATION CONDITIONS}

Measuring operation conditions, i.e. in-plane irradiance, $G$, and cell temperature, $T_{\mathrm{C}}$, is a requirement for PV array characterization. Looking for repeatability, spectral, angular and thermal responses, the respective sensors should behave like the PV array modules. This is best

(a)

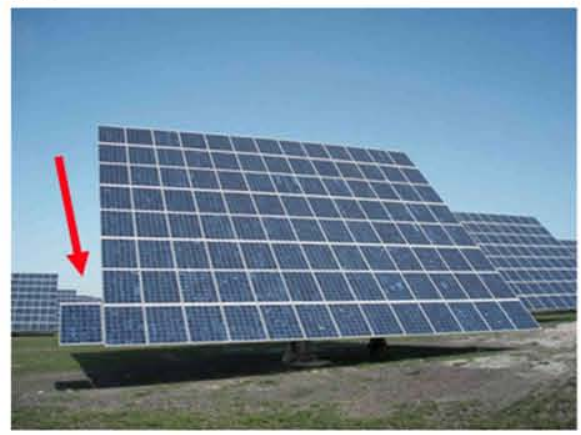

accomplished by using 'reference' modules. These devices are not usually commercially available, so that they must be specifically prepared, which means stabilization followed by calibration. The stabilization requirements are given at international standards IEC-61215 and IEC$61646[20,21]$. In any case, this makes a minimum Sun exposition of $60 \mathrm{kWh} / \mathrm{m}^{2}$ compulsory. It is worth mentioning that round-robin tests performed in European laboratories have shown calibration accuracy better than $2 \%$ for crystalline silicon modules [22]. Moreover, it is sometimes difficult to find a free place and means of fixing the two required 'reference' modules on the existing PV array structures. This is often the case with trackers. Then, a nice possibility is to use only one 'reference' module as the unique sensor of both $G$ and $T_{\mathrm{C}}$. Figure 2 shows how to do it, adding a connection box to the module that includes a shunt resistor and the wiring to obtain both signals simultaneously. Thus, a part of the module can be shortcircuited with a shunt resistor, for measuring $G$, keeping the other part in open-circuit, for measuring $T_{\mathrm{C}}$.

'Reference' modules should be installed at places providing representative values of $G$ and $T_{\mathrm{C}}$ for the full PV array (somewhere between the edge and the center of the ground covered by the PV array, at half its height). Moreover, in order to be affected by similar soiling, they should be installed some time before the beginning of test. Two weeks is an appropriate rule. Other authors also declare that the use of 'reference' modules is highly suitable for testing PV arrays [9,23]. Published experience regarding other commercial devices (piranometers and reference cells) seems not to be so positive [24].

(b)

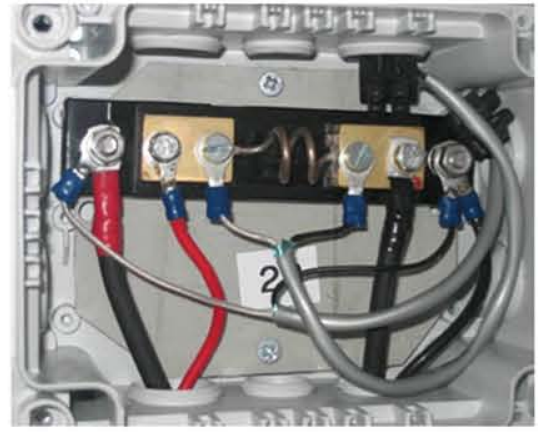

(c)

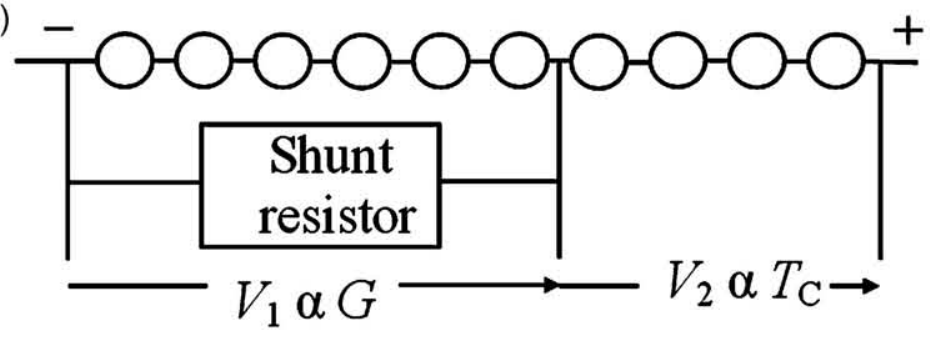

Figure 2. (a) Unique module as both $G$ and $T_{\mathrm{C}}$ sensor placed on an extra structure added to the tracker. (b) Connection box added to the module with a shunt resistor and the wiring to get both signals simultaneously. (c) Scheme of the module modified to measure both operation conditions $G$ and $T_{C}$. Circles represent solar cells, and its number is generic. 


\section{TESTING WITH I-V TRACERS}

The largest $I-V$ tracer commercially available today is limited to $100 \mathrm{~A}$ [25]. However, PV arrays of up to $500 \mathrm{~kW}$ are currently on the market. This has lead us to build our own equipment which is able to measure currents of up to $400 \mathrm{~A}$ by upgrading a previous capacitive load based on IGBT [26]. $I-V$ measurements offer two main advantages. On the one hand, they are obtained relatively quickly, thus many PV arrays can be measured in only 1 day. On the other hand, they allow for knowing not only the effective peak power of the PV array, $P^{*}{ }_{\mathrm{M}}$ (in what follows, the superscript * stands for STC), but also the full $I-V$ curve, which is a useful tool for diagnosing possible anomalies. For example, Figure 3 shows the normalized $I-V$ curve corresponding to PV arrays affected by hot-spots (triangles) and the so-called 'polarization' (squares). These anomalies are reflected in the strange shape of the curve around the knee.

The main inconvenience is the rather significant uncertainty associated to the determination of $T_{\mathrm{C}}$. The more extended the PV array and the larger the wind speed, the larger the temperature spread inside the PV array and, therefore, the value given by a single PV reference module is less representative. As a representative case, Figure 4 shows the $P^{*}{ }_{\mathrm{M}}$ values measured with our $I-V$ tracer on many different days over a year at a $1.3 \mathrm{~kW}$ PV array existing at the IES-UPM terrace. Despite the relatively low size of this PV array, about a $12 \mathrm{~m}^{2}$, uncertainty is as large as $\pm 5.5 \%$. Whichever the case, in order to keep uncertainty low, it is convenient to adopt some precautions: use a load capacitor large enough to obtain charging times of above $20 \mathrm{~ms}[23,26-28]$; assure that $G$ is larger than $800 \mathrm{~W} / \mathrm{m}^{2}$; and limit wind speed to below $5 \mathrm{~m} / \mathrm{s}$ [29]. However, it must also be mentioned that this is not without cost in terms of time restrictions.

$I-V$ curves obtained under real operating conditions should be extrapolated to STC according to well-defined

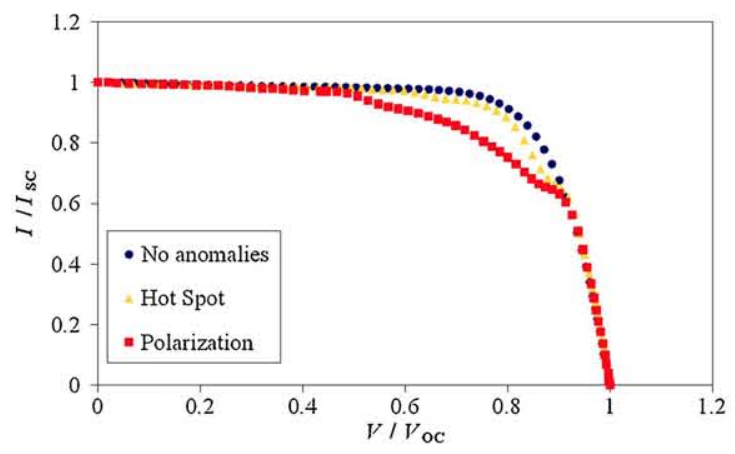

Figure 3. $1-V$ curves corresponding to $P V$ arrays affected by hotspots and polarization. All these curves have been normalized to best compare their shapes. The $I-V$ circle curve belongs to a PV array with no anomalies; the triangle one belongs to a PV array with hot-spots; and the square one belongs to a PV array affected by the so-called 'polarization'.

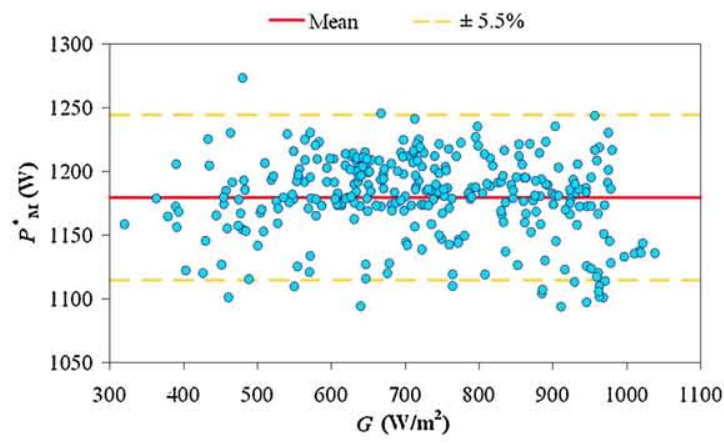

Figure 4. $P^{*}$ v values calculated on many different days over a year at a $1.3 \mathrm{~kW}$ PV array existing at the IES-UPM terrace. The uncertainty of the obtained values is as large as $\pm 5.5 \%$.

procedures $[6,7]$ and using correction temperature, values provided by the PV module manufacturer. It is worth mentioning that in practise, this represents an additional source of uncertainty due to possible inconsistencies and lack of representation of these values. Figure 5 shows an example of a measured $I-V$ curve (circles) with $I_{\mathrm{sc}}=314 \mathrm{~A}, V_{\mathrm{oc}}=699 \mathrm{~V}, P_{\mathrm{M}}=146947 \mathrm{~W}$ and its extrapolation to STC (triangles) in accordance with IEC-60891 using current and voltage temperature coefficients, $\alpha=0.06 \% / \mathrm{K}$ and $\beta=-0.37 \% / \mathrm{K}$, respectively. The result is $P^{*}{ }_{\mathrm{M}}=158092 \mathrm{~W}$. An alternative way of deriving $P^{*}{ }_{\mathrm{M}}$ consists of, first, obtaining the maximum power of the measured curve, $P_{\mathrm{M}}$, and second, translating this value by using the equation:

$$
P_{M}^{*}=P_{M} \cdot \frac{G^{*}}{G} \cdot \frac{1}{\left[1+\gamma \cdot\left(T_{C}-T_{C}^{*}\right)\right]}
$$

where $\gamma$ is the power temperature coefficient provided by the PV module manufacturer. Ideally, both results should fully coincide. However, in this particular case,

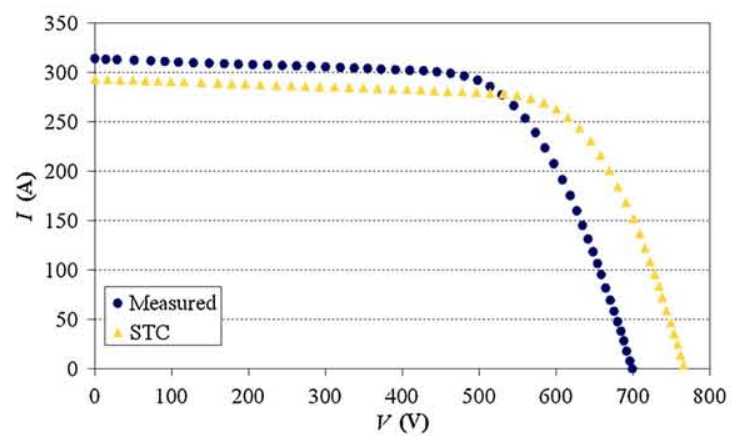

Figure 5. $1-V$ curve measured (circles) with the IES-UPM tracer and the extrapolated one (triangles) in accordance with IEC60891 recommendations. The measured short-circuit current reaches $314 \mathrm{~A}$, far away from existing commercial equipments (limited to $100 \mathrm{~A}$ ). The measured open-circuit voltage reaches $699 \mathrm{~V}$ and the maximum power point is $146947 \mathrm{~W}$. 
$P_{\mathrm{M}}=146947 \mathrm{~W}, \gamma=-0.45 \% / \mathrm{K}$ and $P^{*}{ }_{\mathrm{M}}=154147 \mathrm{~W}$, which differs from the former by $2.5 \%$. Our experience includes differences of up to $5 \%$. So, due to the uncertainty related to $I-V$ tracer measurements, we do not recommend them for contractual purposes, but only for PV plant stateof-health analysis. It is worth mentioning that Equation (1) and the following ones disregard the variation in module efficiency at low irradiances because the measurements take into account to obtain the PV array effective power are those ones related to irradiances above $800 \mathrm{~W} / \mathrm{m}^{2}$.

\section{TESTING WITH WATTMETERS}

More accurate results are obtained by observing the DC power at the output of the $\mathrm{PV}$ array, $P_{\mathrm{DC}}$, over a relatively long time (at least one full day). Thus, a time series of $\left[P_{\mathrm{DC}}\right.$, $\left.G, T_{\mathrm{C}}\right]$ values is obtained. Then, a useful way of deriving $P^{*}{ }_{\mathrm{M}}$ consists of, first, correcting the actual $P_{\mathrm{DC}}$ values to $25^{\circ} \mathrm{C}$, by means of Equation (2):

$$
P_{\mathrm{DC}}\left[G, 25^{\circ} \mathrm{C}\right]=\frac{P_{\mathrm{DC}}}{\left[1+\gamma \cdot\left(T_{\mathrm{C}}-T_{\mathrm{C}}^{*}\right)\right]}
$$

And second, to obtain the best fit for Equation (3):

$$
P_{\mathrm{DC}}\left[G, 25^{\circ} \mathrm{C}\right]=\frac{P_{M}^{*}}{G^{*}} \cdot G
$$

In practise, the latter requires the previous filtering of values in order to avoid the influence of operational anomalies, such as shade on the PV array or on the 'reference' module, inverter saturation, inverter-off, low irradiances, etc. Figure 6 shows the whole set of $\left[P_{\mathrm{DC}}, G\right.$, $T_{\mathrm{C}}$ ] values measured at the output of a $160 \mathrm{~kW}$ nominal PV array over a full day with a 60-s sampling time and Figure 7 the set of $\left[P_{\mathrm{DC}}, G, T_{\mathrm{C}}\right]$ values surviving after this filtering

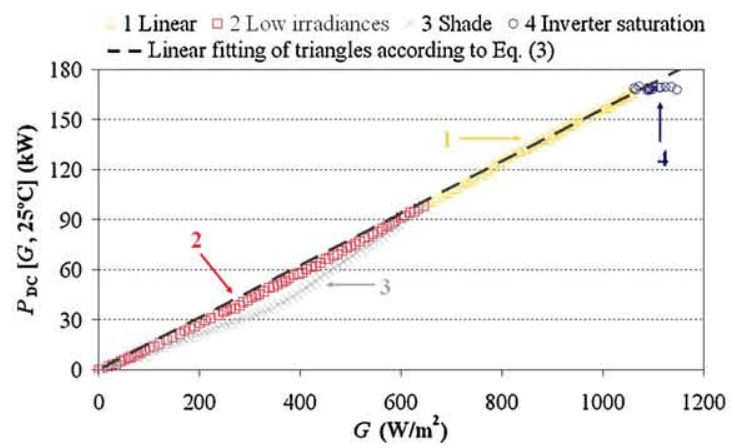

Figure 6. $P_{\mathrm{DC}}$ values measured with wattmeter over a full day at the output of a $160 \mathrm{~kW}$ nominal PV array and corrected to $25^{\circ} \mathrm{C}$ (by using Equation (2)) versus irradiance. Four different behaviors can be distinguished: 1 Linear behavior (triangles); 2 Sublinear behavior because of lower PV module efficiency at low irradiances (squares); 3 More sublinear behavior at low irradiances because of shade cast over the PV array (crosses); 4 Horizontal behavior at high irradiances because of inverter saturation (circles). The discontinuous line is the best fit for linear behavior.

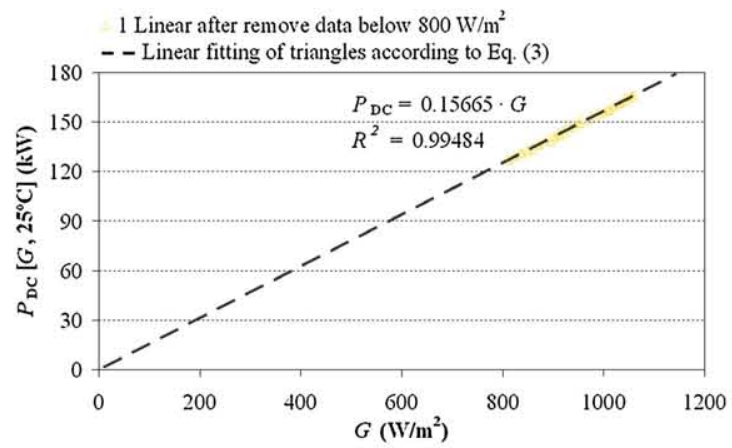

Figure 7. $P_{\mathrm{DC}}$ values from Figure 6 after remove the data related to irradiances below $800 \mathrm{~W} / \mathrm{m}^{2}$ and inverter saturation. The values surviving this filtering process are used to calculate the best fit of Equation (3) in order to obtain $P^{*}{ }_{M}$.

process, with $G>800 \mathrm{~W} / \mathrm{m}^{2}$, and the best fit of Equation (3). The result is $P^{*}{ }_{\mathrm{M}}=156650 \mathrm{~W}$.

It must be noted that this procedure relies on two different assumptions: first, the inverter perfectly follows the MPP of the PV array, and, second, the error resulting from the spread on the solar cell temperature throughout the PV array behaves as a zero mean random variable. According to other authors [30], the first is $99 \%$ true with most current inverters and, according to our experience, the second is also true if the 'reference' module is located in a representative place (somewhere between the edge and the center of the PV array, at half its height), if the length of the experiment is at least one full day, and the sampling time is equal to or lower than $1 \mathrm{~min}$. Additional recommendations are: consider the PV array output as close as possible to the inverter entry, in such a way that mismatching and DC wiring losses are included in the PV array; measure DC currents by means of class 0.5 shunt resistors or similar devices; avoid extremely windy days, and impose $G>800 \mathrm{~W} / \mathrm{m}^{2}$; and, finally, consider the fact that the reference module is in open circuit whereas the PV array is delivering power, hence slightly colder [31-33]. It is easy to see that the following equation applies:

$$
T_{\mathrm{C}, \mathrm{A}}=T_{\mathrm{C}, \mathrm{RM}}-\frac{\mathrm{NOCT}-20}{800} \cdot G \cdot \eta\left(G, T_{\mathrm{C}}\right)
$$

where $T_{\mathrm{C}, \mathrm{A}}$ is the array cell temperature, $T_{\mathrm{C}, \mathrm{RM}}$ is the reference module cell temperature, NOCT is the nominal operation cell temperature and $\eta\left(G, T_{\mathrm{C}}\right)$ is the module efficiency.

$$
\eta\left(G, T_{\mathrm{C}}\right)=\eta^{*} \cdot\left[1+\gamma \cdot\left(T_{\mathrm{C}}-T_{\mathrm{C}}^{*}\right)\right]
$$

An advantage of using a wattmeter is that inverters ranging from $\mathrm{kW}$ to $\mathrm{MW}$ can be tested with the same equipment just by selecting the adequate shunt resistor size to install at the inverter entry. As a curiosity, our present experience includes the testing of a $562 \mathrm{~kW}$ PV array, using a $1000 \mathrm{~A} / 150 \mathrm{mV}$ shunt resistor. This could be the largest PV array ever tested all around the world. 


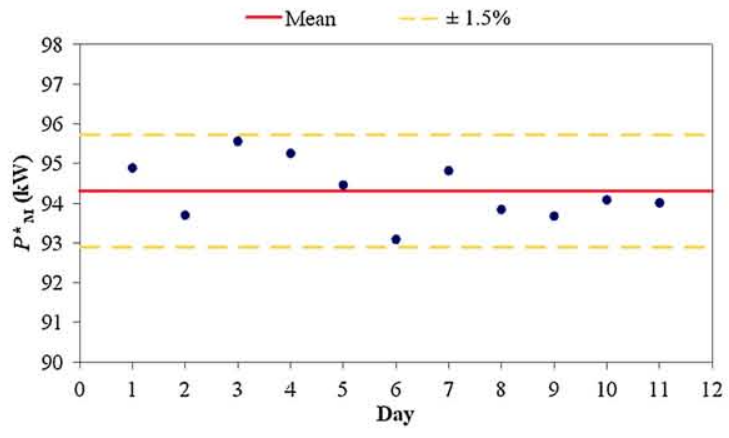

Figure 8. $P^{*}{ }_{M}$ values calculated with wattmeter over 11 days at the output of a $100 \mathrm{~kW}$ nominal PV array. Daily results are plotted with circles and the mean result is represented by the continuous horizontal line. Discontinuous lines mark the $1.5 \%$ difference from mean.

Figure 8 shows the daily results of measuring a PV array of $100 \mathrm{~kW}$ over eleven consecutive days. It can be seen that differences between mean (horizontal line) and individual days (points) are $<1.5 \%$ (marked by discontinuous lines).

Whatever the case, measuring $\mathrm{AC}$ power can increase the confidence of the PV plant results. In effect, energy calculated as the integral of the AC power measurements can be compared with the energy given by standard energy meters, typically existing in any PV plant. That allows tie the PV plant characteristics resulting from tests with the energy effectively sell to the grid. According to our experience, this tying is greatly appreciated in PV commercial scenarios.

In particular, when very large PV arrays are concerned, dealing with DC currents becomes cumbersome due to the practical difficulties in inserting a large shunt resistor at the inverter entry. In some cases this is even nearly impossible. Then, it is still possible to derive $P^{*}{ }_{\mathrm{M}}$ from just $\mathrm{AC}$ power measurements at the inverter output providing that the inverter efficiency and the size and length of the wiring are properly known. Note that AC currents can be accurately measured with AC clamps, which are easy to handle. According to our experience [3], using the information on inverter efficiency provided by their manufacturers for the inverter and wiring together use to be better than $98 \%$ accurate at high power levels.

\section{CONCLUSIONS}

This paper has reported on the IES-UPM experience in the field-testing of large PV arrays. $I-V$ curve measurements with $I-V$ tracers are quick and allow PV array anomalies to be detected. However, the corresponding measured power encompasses too much uncertainty to be taken into account contractually. Power measurements using wattmeter provide more accurate power results, especially if the following precautions for reducing uncertainty are taken into account:
- Use 'reference' modules stabilized and calibrated by accredited laboratories as $G$ and $T_{\mathrm{C}}$ sensors.

- Install them some time before the beginning of testing to be affected by similar soiling as that of the PV array.

- Take into account that the 'reference' module acting as solar cell temperature sensor is in open circuit and, then, slightly hotter than the PV array.

- Use a shunt resistor at the inverter entry to get accurate DC current measurements.

- Get samples every minute (or quicker) at least for one full day.

- Avoid extremely windy days (wind speed $<5 \mathrm{~m} / \mathrm{s}$ ).

- Impose $G>800 \mathrm{~W} / \mathrm{m}^{2}$.

PV arrays up to a total of $200 \mathrm{MW}$ have been tested within the framework of Spanish commercial PV plants, leading us to believe that STC power values calculated at the inverter entry can be properly considered in quality control procedures of large PV plants.

\section{REFERENCES}

1. Real Decreto 661/2007. Official State Gazette (BOE), number 126/2007, 22846-2288 6. http://www.boe.es.

2. Dirección de Energía Eléctrica. Información estadistica sobre las ventas de energía del Régimen Especial. Reference: IAP_ventas_RE_Jun_2010. The National Energy Commission, 2010. http://www.cne.es.

3. Muñoz J, Martínez-Moreno F, Lorenzo E. On-site characterisation and energy efficiency of grid-connected PV inverters. Progress in Photovoltaics: Research and Applications, n/a. DOI:10.1002/pip.

4. IEC Standard-60904-1. Photovoltaic Devices. Part 1: Measurements of Photovoltaic Current-Voltage Characteristics. International Electrotechnical Commission. 2006.

5. IEC Standard-61829. Crystalline Silicon Photovoltaic (PV) Array-On-site Measurements of I-V Characteristics. International Electrotechnical Commission. 1995.

6. IEC Standard-60891. Photovoltaic Devices. Procedures for Temperature and Irradiance Corrections to Measured I-V Characteristics. International Electrotechnical Commission. 2009.

7. Blaesser G, Munro D. Guidelines for the assessment of photovoltaic plants. Document C: Initial and periodic tests on photovoltaic plants. Joint Research Centre of the European Communities, Ispra Establishment 1995, Report EUR 16340 EN.

8. Spertino F, Abete A, Napoli R. Experimental testing of grid-connected PV Systems with different power in order to assess the yearly energy production. 21st European Photovoltaic Solar Energy Conference, 2312-2315, Dresden, Germany, 2006.

9. King DL, Boyson WE, Kratochvil JA. Photovoltaic array performance model. Sandia National Laboratories, Report SAND2004-3535, 2004. 
10. Alonso Abella M, Silva JP, Fabero F, Vela N, Chenlo F. PV module Peak power: comparison between manufacturer data and laboratory results. 23rd European Photovoltaic Solar Energy Conference, 2837-2840, Valencia, Spain, 2008.

11. Alonso M, Silva JP, Chenlo F, Fabero F, Vela N. Aceptación de módulos fotozoltaicos para grandes centrales. XIV Congreso Ibérico y IX Congreso Iberoamericano de Energía Solar, Vigo, Spain, 2008; 2: 991-996.

12. Steland A, Herrmann W. 2010; Evaluation of photovoltaic modules based on sampling inspection using smoothed empirical quantiles. Progress in Photovoltaics: Research and Applications 18: 1-9. DOI:10.1002/pip.926.

13. Schlumberger A, Kreutzmann A. A burning problem. Defective BP modules a fire hazard. The Photovoltaic Magazine, 14-16, August 2006.

14. Welter P. These cells are simply too good. An explanation of poor yields from Sunpower's modules Photon International. The Photovoltaic Magazine, 68, May 2006.

15. Schlumberger A. Módulos estrella se comportan como divas caprichosas. Photon. La revista de fotovoltaica, 112-114, April 2007.

16. Rutschmann I. Siempre se aprende algo nuevo. Photon. La revista de fotovoltaica, 110-111, Enero 2008.

17. Munoz MA, Alonso-García MC, Chenlo F. Early degradation of $P V$ modules and guaranty conditions. 24th European Photovoltaic Solar Energy Conference, 3565-3568, Hamburg, Germany, 2009.

18. Munoz MA, Silva JP, Chenlo F. Influence of initial power stabilization over PV modules maximum power. 24th European Photovoltaic Solar Energy Conference, 3464-3467, Hamburg, Germany, 2009.

19. Muñoz J, Lorenzo E, Martínez-Moreno F, Marroyo L, García M. An investigation into hot-spots in two large grid-connected PV plants. Progress in Photovoltaics: Research and Applications 2008; 16: 693-701. DOI:10.1002/pip.844.

20. IEC Standard-61215. Crystalline silicon terrestrial photozoltaic (PV) modules. Design qualification and type approzal. International Electrotechnical Commission. 2005.

21. IEC Standard-61646. Thin-film terrestrial photovol taic (PV) modules. Design qualification and type approval. International Electrotechnical Commission. 2008.
22. Hermmann W, Mau S, Fabero F, Betss T, Van der Borg N, Kiefer K, Friesen G, Zaaiman W. Advanced intercomparison testing of $P V$ modules in European test laboratories. 22nd European Photovoltaic Solar Energy Conference, 2506-2510, Milan, Italy, 2007.

23. Fabero F, Vela N, Alonso-Abella M, Chenlo F. Characterization of recent commercial technologies of PV modules based on outdoor and indoor I-V curve measurements. 20th European Photovoltaic Solar Energy Conference, 2059-2062, Barcelona, Spain, 2005.

24. Düpont R. Cada uno mide como puede. Photon. La revista de fotovoltaica, 42-60, Noviembre 2009.

25. Neuenstein J, Podewils C. Los módulos y sus curvas. Photon. La revista de fotovoltaica, 54-71, 2009.

26. Muñoz J, Lorenzo E. Capacitive load based on IGBTs for on-site characterization of PV arrays. Solar Energy 2006; 80(11): 1489-1497.

27. Mahmoud MM. Transient analysis of a PV power generator charging a capacitor for measurement of the I-V characteristics. Renewable Energy 2006; 31: 2198-2206.

28. Zdanowicz T. Common pitfalls and error sources occurring during outdoor monitoring of PV modules. 20th European Photovoltaic Solar Energy Conference, 2109-2112, Barcelona, Spain, 2005.

29. Nofuentes G, Aguilera J, Santiago RL, De La Casa J, Hontoria L. 2006; A reference-module-based procedure for outdoor estimation of crystalline silicon PV module peak power. Progress in Photovoltaics: Research and Applications 14: 77-87. DOI:10.1002/ pip.636.

30. Haeberlin H, Borgna L, Kaempfer M, Zwahlen U. New tests at grid-connected PV Inverters: overview over test results and measured values of total efficiency $\eta$ tot. 21st European Photovoltaic Solar Energy Conference, 2153-2156, Dresden, Germany, 2006.

31. Auer R, Jahn U, Buerhop-Lutz B. Infrared analysis of PV modules for improving quality. 22nd European Photovoltaic Solar Energy Conference, 2519-2522, Milan, Italy, 2007.

32. Nieto MB, Silva JP, Chenlo F. Diferencia de temperatura de operación de módulos FV según tecnologia de celulas y tipo de encapsulado. XIV Congreso Ibérico y IX Congreso Iberoamericano de Energía Solar, Vigo, Spain, 2008; 2:727-732.

33. Tina GM, Abate R. Experimental verification of thermal behaviour of photovoltaic modules. 14th IEEE Mediterranean Electrotechnical Conference, MELECON 2008, 579-584. DOI:10.1109/MELCON.2008. 4618497 . 